\title{
Ratio Analysis to Measuring Financial Performance of PT. Indosat Tbk. Listed in IDX (Period 2015-2018)
}

\author{
Eva Putri Priari ${ }^{1}$, Ani Wulandari ${ }^{2}$ \\ evaputripriari17@gmail.com ${ }^{1}$, ani.wulandari@ narotama.ac.id ${ }^{2}$ \\ Department Of Management, Faculty of Economic and Business, Narotama University \\ Jl. Arief Rahman Hakim 51, Surabaya, Indonesia 60117..,2
}

\begin{abstract}
A company's health assessment can be done by analyzing the financial statements to Determine the performance of its finances. One of the analytical tools that can be used is the analysis of financial ratios. This research aims to analyze the financial performance of PT. Indosat Tbk. Is reviewed restaurants from the financial ratio analysis. The methods used are the data analysis using descriptive qualitative measurements liquidity ratio, solvency, profitability, and activity. The results Showed that the financial performance of PT. Indosat Tbk. Based on the overall liquidity ratio of the company in a good condition (liquid). The overall solvency ratio of the company is said to be solvable or in good condition to guarantee its debts. The company's profitability ratio is at a less than good position (inefficient). While at the ratio of its activity the company is said to be less efficient.
\end{abstract}

Keywords: financial statements, financial ratios, financial performance.

\section{INTRODUCTION}

The rapidly expanding business world in this digitisation era, and more and more new companies make companies to be more effective in running the wheels of the company organization. So the company is required to have competitive ability, both locally oriented and internationally oriented competitors. Companies generally have a desire to achieve one particular goal. The success of achieving the company's objectives is highly determined by the performance of the company itself and should also have a mature strategy in every way included in financial management. Financial management is very influential about the company's existence in order to carry out operational activities can be more effective and efficient. A company owner is required to be able to implement financial management well so that the company can develop and maintain the company's activities and existence in today's global competition.

One way that can be used to see the health of the company is to look at the financial statements, because to know the performance of a company is through financial statements, where the financial statements contain information that Related to financial position, business outcomes and financial position changes in the company. To assess the company's financial performance, it is not enough to see only financial statements. New financial statements can provide a useful information for a company owner if they have conducted an analysis of the financial statements.

Analysis of the company's financial statements is an activity that can provide information about the company's financial health at a certain period. The information is used by the company to determine how the level of performance and use as a reference or foundation in the decision making. In conducting assessments of the company's performance requires several benchmarks. The commonly used benchmark is a ratio calculation that combines two financial data with one another.

Financial ratios are instructions directing the management of a company to set various targets and standards. The financial ratios are very helpful to the company's owners in establishing profitable long-term strategies and in making short-term decisions more effective and efficient for the company.

The analysis of this financial ratio can help managers to know the level of financial performance of the company whether good or otherwise. Ratio analysis is clarified in various types, namely liquidity ratio, solvency, activity, and profitability. So in order to evaluate the performance of the company need analysis on financial statements using financial ratio calculation. From the results of the analysis will be obtained an overview of business developments in a company and can be used as a basis for decision making for both internal and external parties.

Given the importance of financial statements in assessing the health of a company, the information from the above financial statements that have been evaluated is necessary for the parties who have an interest in the financial condition and the outcome of Operation of the company. The parties 
interested in the financial statements include the owner of the company, investors, creditors, banker, and government.

At the telecommunications sector business, during the year 2018 suffered heavy challenges for the first time. That affects the decline in the telecommunications sector one of them is the mobile phone users consume more data than phone or SMS service. Tariff wars on data services are also the cause of the revenue decline. Phone and SMS services suffered the most sharp decline. In 2018, the decline was quite significant to $30 \%$. As a result of data service tariff competitions, per megabyte revenue is also down $17 \%$. In addition, the telecommunications sector company was also depressed by the negative sentiment of the SIM Card registration obligation, as a result of the registration of SIM card number of customers dropped from 306 million customers in the I-2018 quarter to 286 million in the II-2018 quarter.

One of the telecommunications sector companies that also experienced a decrease in revenue is PT Indosat TBK. In addition to the problems above the company is also too much to run a policy to Reward consumers, where the discounted value is above expectations. In Indosat's financial statement, the total discount and customer loyalty program reached $\mathrm{Rp} 1.6$ trillion. This figure is greater than the amount of discount issued in the previous year of $\mathrm{Rp} 1.2$ trillion. Indosat is also still stuck in jumbo Internet quota bidding program at a cheap price, which is done through the promotion program "Youtube Without Limits". Indosat revenue in year 2018 amounted to 23.1 trillion rupiah while revenues in 2017 amounted to 29.9 trillion rupiah, obviously Indosat experienced a decrease in revenue in the year 2017-2018 by $22.7 \%$. While in the year 2017, Indosat scored a net profit of 1.13 trillion rupiah. These things are the cause of the company's financial performance. In order to keep the financial performance of the telecommunications company, it is necessary to evaluate its financial performance, one of which is to use the technical analysis of performance. Analysis of financial performance by the company today based on the analysis of financial ratios.

Based on the background description that has been outlined, then the problem formulation that will be discussed in this research is how is the financial performance with the ratio method of PT. Indosat TBK from 2015 to 2018?. Related to the above problem, the goal that is to be achieved in this research is to analyze the financial performance of PT. Indosat TBK is reviewed from the financial ratio analysis.

\section{LITERATURE REVIEW}

\section{Financial statements}

The definition of financial statements according to Cashmere (2015:7) Financial statements are reports indicating the company's financial condition at the moment or in a certain period. Financial statements are made per period, for example three months, or six months for the company's internal interests. Meanwhile, for a wider report is done once a year.

\section{Objectives of financial statements}

The objectives of financial statements according to Harahap (2015:132) are:

a) To provide reliable financial information about the economic resources and obligations and capital of a company.

b) To provide reliable information about changes in the net economic resources (source minus the obligation) of a company arising from the business activity in order to obtain profit.

c) To provide financial information that helps users report in estimating the company's potential in generating profits.

d) To provide other important information about changes in economic sources and obligations, such as information on spending and planting activities.

e) To disclose to the extent possible other information relating to the relevant financial statements to the needs of the wearer's financial statements, such as information about the accounting discretion that the company embraced.

\section{Financial Report Form}

There are two main types of financial statements commonly made by each company:

a. Balance sheet

Balance sheet is a financial statement that provides information about the financial position (equity, assets, liabilities) of the company at a certain time

b. Profit/Loss Report

Profit/Loss report is a financial statement that provides information about the company's ability to generate performance profits over a certain period. 


\section{Financial performance}

Jumingan (2014:239) Financial performance is a description of the financial condition of a certain period whether it concerns the aspects of gathering funds and the distribution of funds usually measured by the capital adequacy indicators, liquidity and profitability.

\section{Financial Report Analysis}

According to the singular (2000:22) analysis and interachievement of financial statements is a tool that can be used to make a decision among other plans of expansion of companies, investing (investment), the search for sources of funds Company operations, and others.

\section{Objective analysis of financial statements}

Harahap (2006:195) revealed that the objectives of the analysis of this financial report are as follows:

1. Can provide broader, deeper information than from the usual financial statements.

2. Can retrieve information that is not visible to the naked eye (expicit) of a financial statement or that is reversed financial statements (implicit).

3. Can find out the errors contained in the financial statements.

4. Can disassemble non-consistent matters in relation to a financial statement both attributed to internal components of financial statements as well as in relation to information on the outside of the company.

5. Know the properties of the relationship that eventually gives birth to the models and theories contained in the field such as for prediction and Enhancement (rating).

6. Can provide the information desired by the decision makers. In other words what is meant by a financial statement is the goal of analysis of financial statements as well:

- Be able to assess company achievements.

- Can project the company's finances.

- Be able to assess the financial condition of the past and present from the specific time aspect: a). Financial position (assets, balance, and capital), B). Company's business results (results and costs), C). Liquidity, D). Solvency, E). Activity, F). Ability or profitability, g). Capital market indicators.

- Assess developments over time.

- View the composition of financial structures and the flow of funds.

7. Can determine the rank of companies according to certain criteria already known in the business world.

8. Can compare the situation of the company with other companies with the previous period or with normal industry standards or ideal standards.

9. Able to understand the situation and financial condition of the company, both financial position, business results, financial structure and so on.

10. It can also predict what potential companies may experience in the future.

\section{Financial Statements Analysis method}

Harahap (2006:216) presented the techniques in the analysis of financial statements as follows:

a. Comparative method

Comparative or comparative methods are used by using the numbers in financial statements and comparing with the figures in the financial statements of the previous year. In other ways, you can compare individual post relevant financial statements or significant data. So this method is also known by the term analysis method ratio.

b. Analysis method

The method uses comparative techniques of financial statements several years, and then illustrates the trend/graph. Therefore, on this method in need of the knowledge help statistics. For example, such as using a linear program formula $\mathrm{Y}=\mathrm{A}+\mathrm{bx}$. Trend techniques can be used to project future financial statements using historical data.

c. Common Size Financial Statement method

This method is an analysis method that makes financial statements in the form of presentations. The presentations are usually related to an important amount of value. For example the asset on the balance sheet, the sales on profit/loss statements.

d. Time Series Index method

This method is calculated by using the financial statement as an index and selected as the base year. Usually the base year selected/assigned is given an index of 100 . 


\section{Financial Ratios analysis}

Munawir (2009:55) financial ratios analysis is one way of processing and interpretation of accounting information expressed in both relative and absolute terms to carry out a specific relationship between a number and other numbers from A financial statement.

\section{Types of financial ratios}

a. Liquidity Ratio

Irham Fahmi (2011:121) defines the ability of a company to fulfill a short term obligation in a timely manner. There are several liquidity ratios that can be used to analyse a company, namely:

1. Current Ratio

2. Cash ratio (Cash Ratio)

3. Quick Ratio (Quick Ratio)

b. Solvency ratio Sutrisno (2009) defines solvency is the ability of the company to fulfill all its obligations when the company is liquidated. The ratio used to measure a company is:

1. Debt to Equity Ratio

2. Debt to Total Assets Ratio

c. Profitability ratio

Sofyan Safri Harahap (2011:304) said that the ratio describing the company's ability to profit through all capabilities, and existing sources such as sales activities, cash, capital, number of employees, number of branches, and so on. Ratio profitability include:

1. Net Profit Margin

2. Return On Assets

3. Return On Equity

d. Activity ratio

The activity ratio is a tool that measures how much effectiveness the company has in using its source funds. The activity ratio is expressed as a comparison of sales with various elements of assets. The more effective it is to utilize the funds, the faster the turnover. The activity ratio is:

1. Total Assets Turnover

2. Inventory Turnover

\section{RESEARCH METHODS}

\section{Research approaches}

This study uses a qualitative descriptive approach of quantitative data. Descriptive research, which is a method used to describe or analyze a research result but not used to make a wider conclusion Sugiyono (2005:21).

\section{Type, source and Data retrieval techniques}

Type of Data

The type of data used in this study is qualitative data which is a data that cannot be measured in numerical scale.

\section{Data Source}

The data source used in this research is secondary data that is the company's financial statements document from 2015 to 2018 from web www.idx.com.

\section{Data Retrieval Techniques}

1. Documentation study is the collection of data obtained from IDX in the form of financial statements.

2. The literature study collects the information obtained using read literature, scientific books, scientific papers, theses, journals or other records that support this research, citing some of the Theories that have been discovered by some experts in relation to the problems discussed in order to obtain data theoretically related to this research.

\section{Variable research and operational definitions}

\section{Variable Research}

The research is compiled using qualitative methods, so it does not use variables. 


\section{Operational definitions}

1. Company financial performance

i.e. ability or achievement, prospects of growth and potential of the company in running its business which is financially demonstrated in financial statements. The company's financial performance assessment is based on evaluation of the company's financial statements, particularly the analysis of financial statements.

2. Financial statements are reports indicating the company's financial condition at the moment or in a certain period. This financial report is measured using the following financial ratios:

a. Liquidity ratio is a ratio for measuring the company's ability to meet short-term financial obligations. Various liquidity ratios are Current Ratio, Quick Ratio, and Cash Ratio for financial report data from year 2015-2018 at PT. Indosat TBK.

b. The solvency ratio is a ratio to measure how much the company is using the funds from the debt (loan). The wide-maca solvency ratio among others is Debt to Total Assets Ratio and Debt to Eauity Ratio for financial report data from 2015-2018 in PT. Indosat TBK.

c. Profitability ratio is the ratio to measure how effective the company is in operating its funds (assets). The various profitability ratios are Net Profit Margin, Return On Assets, and Return On Equity for financial report data from 2015-2018 at PT. Indosat TBK.

d. Activity ratio is a ratio for measuring overall management activity as demonstrated by profits gained from sales and investments. The various activity ratios include Total Assets Turnover and Inventory Turnover for financial report data from 2015-2018 in PT. Indosat TBK.

Data Analysis Techniques

The data analysis technique used is to use a qualitative descriptive approach method of quantitative data, which is to explain the results of the research in the form of financial reporting data that has a connection to the company's performance resulting in a clear picture of the actual condition. Therefore the steps performed are as follows:

1. Collecting the financial statement data of PT. Indosat TBK during the period 2015-2018.

2. Recapitulation of INDOSAT's annual financial statements into the Exel, which is the balance sheet and profit and loss report.

3. Analyzing financial statements using the financial ratios of the ratio of liquidity, solvency ratio, profitability ratio and activity ratio of PT. Indosat.

4. Create the calculation of Indosat's financial ratios during the period 2015-2018.

5. Conducting analysis and interceptional of Indosat's financial performance for the calculation of financial ratios during the period 2015-2018.

6. Give conclusions and suggestions.

\section{RESULTS OF RESEARCH AND DISCUSSION}

\section{Data Analysis and discussion}

\section{Liquidity ratio}

The ratio of liquidity calculated in the study is as follows:

1. Current Ratio is a comparison of current assets with current debt (curent liabilities). The high Current ratio provides an indication of a good guarantee for short term creditors in the sense that each company has the ability to pay off its shorter term financial obligations. The following is presented calculation of the current ratio of PT. Indosat Tbk. Studied from Ahun 2015 until year 2018:

Table 1 Current Ratio PT. Indosat Tbk.

During the Years 2015-2018

\begin{tabular}{|c|c|c|c|}
\hline Year & Current assets & Current liabilities & Current Ratio \\
\hline $\mathbf{2 0 1 5}$ & 9918677 & 20.052600 & 0,495 \\
$\mathbf{2 0 1 6}$ & 8073481 & $19,086,592$ & 0.423 \\
$\mathbf{2 0 1 7}$ & 9479271 & $16,200,457$ & 0.585 \\
$\mathbf{2 0 1 8}$ & 7906525 & $21,040,365$ & 0.376 \\
\hline
\end{tabular}

Source: Secondary Data processed, 2019

Thus it is known during the year 2015-2018 average current ratio of PT. Indosat Tbk. By $46.98 \%$ 
meaning every Rp. 1 Current debt can be guaranteed by the current assets of Rp. 46.98. The high current ratio provides a good indication of the guarantee for short-term creditors in the sense that every moment the company has the ability to pay off its short-term financial obligations.

2. Cash Ratio is a ratio to measure the ability of the company to meet the debt that must be immediately settled with cash available in the company. This ratio is a comparison between cash and smooth debts. The following is presented calculation of the current ratio of PT. Indosat TBK. Studied from 2015 to 2018 :

Table 2 Cash Ratio PT. Indosat Tbk.

During the Years 2015-2018

\begin{tabular}{|l|r|r|r|}
\hline Year & Cash & Current liabilities & cash Ratio \\
\hline $\mathbf{2 0 1 5}$ & 3623346 & 20.052600 & .181 \\
$\mathbf{2 0 1 6}$ & 1959018 & $19,086,592$ & .103 \\
$\mathbf{2 0 1 7}$ & 1778043 & $16,200,457$ & .110 \\
$\mathbf{2 0 1 8}$ & 1142137 & $21,040,365$ & 0,054 \\
\hline
\end{tabular}

Source: Secondary Data processed, 2019

It is thus known that during the year 2015-2018 the average cash ratio of PT. Indosat TBK. amounted to $11.20 \%$. The low Cash ratio provides an indication of less good guarantees for shortterm creditors in the sense that the company lacks the ability to cover cash due to the increasing current debt.

\section{Solvency ratio}

The ratio of solvency calculated in this study is as follows:

1. Debt to Total Assets Ratio, is the ratio between the debt and the total assets expressed in the percentage. The following is presented the calculation of debt to assets ratio of PT. Indosat Tbk. Studied from Ahun 2015 until year 2018:

Table 3 Debt to Total Assets Ratio PT. Indosat Tbk. During the Years 2015-2018

\begin{tabular}{|l|r|r|r|}
\hline Year & Total Amoun of debt & \multicolumn{1}{c|}{ Total assets } & \multicolumn{1}{|c|}{ DAR } \\
\hline $\mathbf{2 0 1 5}$ & $42,124,676$ & $55,388,517$ & 0.761 \\
$\mathbf{2 0 1 6}$ & $36,661,585$ & $50,838,704$ & 0.721 \\
$\mathbf{2 0 1 7}$ & $35,845,506$ & 50.6610400 & 0.708 \\
$\mathbf{2 0 1 8}$ & 41.0033400 & $53,139,587$ & 0.772 \\
\hline
\end{tabular}

Source: Secondary Data processed, 2019

Thus, it can be noted that during the year 2015-2018 the average debt to total asset ratio of PT. Indosat Tbk. Amounted to $74.05 \%$ meaning every Rp 1 total debt can be guaranteed by total assets of $\mathrm{Rp} 74.05$. The higher the ratio, the higher the risk facing the company and the lender will ask for a high level of profit from the funds lent to the company and vice versa the lower the ratio then the lower the risk Faced by the company.

2. Debt to Equity Ratio, is the total ratio of debt to its own capital is a total comparison of debts owned by the company with its own capital. The following is presented calculation of debt to total equity ratio of PT. Indosat Tbk. Studied from Ahun 2015 to 2018:

Table 4 Debt to Equity Ratio PT. Indosat Tbk.

During the Years 2015-2018

\begin{tabular}{|l|r|r|r|}
\hline Year & total Liabilities & Equitas & DER \\
\hline $\mathbf{2 0 1 5}$ & $42,124,676$ & $13,263,841$ & 3.176 \\
$\mathbf{2 0 1 6}$ & $36,661,585$ & $14,177,119$ & 2.586 \\
$\mathbf{2 0 1 7}$ & $35,845,506$ & $14,815,534$ & 2,419 \\
\hline
\end{tabular}

Source: Secondary Data processed, 2019

Thus it can be known that during the year 2015-2018 the average debt to total equity ratio of PT. Indosat Tbk. Amounted to $28.90 \%$ meaning every Rp 1 total debt can be guaranteed by its own capital of Rp 28.90. PT. Indosat TBK prioritizes funds derived from creditors from the company's 
own capital. The higher the debt to Total equity (DER) ratio indicates the proportion of its own capital to fund debts.

\section{Profitability ratio}

The ratio of profitability calculated in this study is as follows:

1. Net Profit Margin (net profit margin) is the profit of the sale after the entire cost and income tax. This Margin shows the comparison of net profit after tax with sales. The following is presented calculation of net profit margin of PT. Indosat Tbk. Studied from Ahun 2015 until 2018:

Table 5 Net Profit Margin PT. Indosat Tbk.

During the Years 2015-2018

\begin{tabular}{|r|r|r|r|}
\hline Year & Net Profit After Tax & Net Sales Revenue & Percentage (\%) \\
\hline $\mathbf{2 0 1 5}$ & $-1,785,835$ & $-1,163,478$ & $15.35 \%$ \\
$\mathbf{2 0 1 6}$ & 1795263 & 1275655 & $14.07 \%$ \\
$\mathbf{2 0 1 7}$ & 1940426 & 1301929 & $14.90 \%$ \\
$\mathbf{2 0 1 8}$ & $-2,663,543$ & $-2,085,059$ & $12.77 \%$ \\
\hline
\end{tabular}

Source: Secondary Data processed, 2019

Thus it can be known that during the 2015-2018 year average net profit margin of PT. Indosat Tbk of $14.27 \%$ means the ratio of $14.27 \%$ means that net profit from sales reached by $14.27 \%$. High NPM signifies a high enterprise's ability to generate profit at a certain level of sales whereas low NPM tends to exhibit company inefficent.

2. Return on Assets (ROA) This ratio measures the profit after tax with the total assets. The following are presented calculation of return on assets (ROA) PT. Indosat Tbk. Studied from Ahun 2015 to 2018:

Table 6 Return on Assets PT. Indosat Tbk.

During the Years 2015-2018

\begin{tabular}{|l|r|r|r|}
\hline Year & Profit After Tax & total Assets & Percentage (\%) \\
\hline $\mathbf{2 0 1 5}$ & $-1,785,835$ & $55,388,517$ & $-3.2 \%$ \\
$\mathbf{2 0 1 6}$ & 1795263 & $50,838,704$ & $3.5 \%$ \\
$\mathbf{2 0 1 7}$ & 1940426 & 50.66104 million & $3.8 \%$ \\
$\mathbf{2 0 1 8}$ & $-2,663,543$ & $53,139,587$ & $-5 \%$ \\
\hline
\end{tabular}

Source: Secondary Data processed, 2019

Thus it can be known that during the 2015-2018 average return on assets of PT. Indosat TBK amounting to- $0.23 \%$ means a ratio of $-0.23 \%$ indicating that the net income of total assets obtained is- $0.23 \%$. The higher the ROA shows the better the efficiency of the company, because the high ROA shows the company's ability to generate profit from the assets used.

3. Return on equity (ROE) or called the moneyability of the capital itself to measure how much profit the owner of the capital itself. The following are presented calculation of return on equity (ROE) of PT. Indosat Tbk. Studied from Ahun 2015 to 2018:

Table 7 Return on Equity PT. Indosat Tbk. During the Years 2015-2018

\begin{tabular}{|l|r|r|r|}
\hline Year & Net Profit After Tax & Equity & Percentage (\%) \\
\hline $\mathbf{2 0 1 5}$ & $-1,785,835$ & $13,263,841$ & $-13.5 \%$ \\
$\mathbf{2 0 1 6}$ & 1795263 & $14,177,119$ & $12.7 \%$ \\
$\mathbf{2 0 1 7}$ & 1940426 & $14,815,534$ & $13.1 \%$ \\
$\mathbf{2 0 1 8}$ & $-2,663,543$ & $12,136,247$ & $-21.9 \%$ \\
\hline
\end{tabular}

Source: Secondary Data processed, 2019

Thus, it can be known that during 2015-2018 the average return on equity of PT. Indosat TBK amounting to- $2.40 \%$ means the company is only able to generate net profit from its own capital of$2.40 \%$. The higher the return or income earned the better the position/position of the company owner.

\section{Activity ratio}

The ratio of activity calculated in this study is as follows:

1. Total Assets Turn Over (TATO) measures the turnover of how many companies use the funds from debts (loans). The following are presented calculation of total assets turn over PT. Indosat Tbk. Studied from Ahun 2015 to 2018: 
Table 8 Total Assets Turnover PT. Indosat Tbk.

During the Years 2015-2018

\begin{tabular}{|r|r|r|r|}
\hline Year & sale & Total assets & \multicolumn{1}{|c|}{$\begin{array}{c}\text { Total Assets } \\
\text { Turnover }\end{array}$} \\
\hline $\mathbf{2 0 1 5}$ & $26,768,525$ & $55,388,517$ & 0,483 \\
$\mathbf{2 0 1 6}$ & $29,184,624$ & $50,838,704$ & .574 \\
$\mathbf{2 0 1 7}$ & $29,926,098$ & 50.66104 million & 0.591 \\
$\mathbf{2 0 1 8}$ & $23,139,551$ & $53,139,587$ & .435 \\
\hline
\end{tabular}

Source: Secondary Data processed, 2019

Thus it can be known that during the 2015-2018 average total assets turn over PT. Indosat TBK of 0.53 times means that each company has been able to produce sales of total assets owned by 0.52 times. This indicates that the company is ineffective in its efforts to be able to generate a good profit from overall managing its assets to its fullest potential.

Financial performance assessment and interpretation of the financial ratios condition of PT. Indosat TBK.

Based on the financial ratio calculation as described in the table above, the financial performance condition of PT. Indosat TBK will be assessed through the company's financial performance which includes the liquidity ratio, solvency ratio, Profitability ratio and activity ratio.

From the results of the above analysis using a financial ratio consisting of liquidity, solvency, profitability, and activities can be assessed the financial performance of PT. Indosat TBK in the period $2015-2018$ as a whole as follows :

Table 9 Assessment of Financial Performance PT. Indosat Tbk.

\section{years 2015-2018}

\begin{tabular}{|c|c|c|c|c|c|c|c|}
\hline $\begin{array}{l}\text { Financial } \\
\text { performance }\end{array}$ & 2015 & 2016 & 2017 & 2018 & $\begin{array}{l}\text { The } \\
\text { average } \\
\text { ratio }\end{array}$ & standart & Information \\
\hline \multicolumn{8}{|l|}{ Liquidity } \\
\hline $\begin{array}{l}\text { a. Current } \\
\text { Ratio }\end{array}$ & $49.50 \%$ & $42.30 \%$ & $58.50 \%$ & $37.60 \%$ & $46.98 \%$ & $20 \%$ & Liquid \\
\hline b. cash Ratio & $18.10 \%$ & $10.30 \%$ & $11 \%$ & $5.40 \%$ & $11.20 \%$ & $\mathbf{5 0 \%}$ & Not Liquid \\
\hline \multicolumn{8}{|l|}{ Solvency } \\
\hline $\begin{array}{l}\text { a. Debt to } \\
\text { Total Assets } \\
\text { Ratio } \\
\text { b. Debt to } \\
\text { Equity Ratio }\end{array}$ & $\begin{array}{l}76.10 \% \\
31.76 \%\end{array}$ & $\begin{array}{l}72.10 \% \\
25.86 \%\end{array}$ & $\begin{array}{l}70.80 \% \\
24.19 \%\end{array}$ & $\begin{array}{l}77.20 \% \\
33.79 \%\end{array}$ & $\begin{array}{l}74.05 \% \\
28.90 \%\end{array}$ & $\begin{array}{l}80 \% \\
90 \%\end{array}$ & $\begin{array}{l}\text { Solvable } \\
\text { Solvable }\end{array}$ \\
\hline \multicolumn{8}{|l|}{ Profitability } \\
\hline a.NPM & $15.35 \%$ & $14.07 \%$ & $14.90 \%$ & $12.77 \%$ & $14.27 \%$ & $10 \%$ & Efficient \\
\hline b. ROA & $-3.20 \%$ & $3.50 \%$ & $3.80 \%$ & $-5 \%$ & $-0.23 \%$ & $30 \%$ & Not Efficient \\
\hline c. ROE & $-13.50 \%$ & $12.70 \%$ & $13.10 \%$ & $-21.90 \%$ & $-2.40 \%$ & $40 \%$ & Not Efficient \\
\hline \multicolumn{8}{|l|}{ Activity } \\
\hline $\begin{array}{l}\text { a. Total } \\
\text { Assets } \\
\text { Turnover }\end{array}$ & 0,483 & .574 & 0.591 & .435 & 0.52 & $2 x$ & Not Efficient \\
\hline
\end{tabular}

Source: Secondary Data, processed 2019

From table 10 calculation, the interachievement of the financial performance condition of PT. Indosat TBK as follows:

1) Condition of financial performance seen from liquidity ratio

a. Current Ratio

Overall average current ratio of PT. Indosat TBK in the period 2015-2018 amounted to $46.98 \%$. Thus the current ratio of PT. Indosat TBK is said to be good because the above average standard numbers.

b. Cash Ratio 
Overall the average cash ratio of PT. Indosat TBK in the period 2015-2018 is $11.20 \%$. Thus the cash ratio of PT. Indosat TBK is said to be less good because it is below the average standard number.

2. Conditions of financial performance seen from the ratio of solvency

a. Debt to Total Asset Ratio

Overall, the average debt to total asset ratio of PT. Indosat TBK in the period 2015-2018 amounted to $74.05 \%$. Thus debt to total asset ratio of PT. Indosat TBK is said to be good because it is below the average standard number.

b. Debt to Total Equity Ratio

Overall, the average debt to total equity ratio of PT. Indosat TBK in the period 2015-2018 amounted to $28.90 \%$. Thus, the debt to equity ratio of PT. H. M Sampoerna TBK is said to be good because it is below the average standard number.

3. Financial performance conditions seen from the profitability ratio

a. Net Profit Margin

Overall, the average net profit margin of PT. Indosat TBK in the period 2015-2018 amounted to $14.27 \%$. Thus net profit margin of PT. Indosat TBK is said to be good because the above average standard numbers.

b. Return on Assets

Overall, the average return on assets of PT Indosat TBK in the period 2015-2018 amounted to- $0.23 \%$. Thus return on assets PT. Indosat TBK is said to be less good because it is below the average standard number.

c. Return on Equity

Overall, the average return on equity of PT Indosat TBK in the period 2015-2018 amounted to- $2.40 \%$. Thus the return on equity of PT. Indosat TBK is said to be less good because it is below the average standard number.

4. Conditions of financial performance seen from the ratio of activity

a. Total Assets Turn Over

Overall, the average total assets turn over PT Indosat TBK in the period of 2015-2018 is 0.52 times. Thus, total assets turn over PT. Indosat TBK is said to be less good because below average standard numbers.

\section{Conclusion}

\section{CONCLUSIONS AND SUGGESTIONS}

Based on the results of the calculation of the analysis conducted on the financial report of PT. Indosat TBK. From the year 2015-2018 using the analysis of liquidity ratios, solvency, profitability, and the known activities of financial performance of PT. Indosat can be withdrawn as follows:

1. Based on the ratio of liquidity for 4 years (year 2015 - year 2018) can be seen the financial performance of PT. Indosat is in good position. Overall the average current ratio is said to be liquid because the average magnitude is above the industry standard average of the financial ratios. But overall the average on cash ratio is said to be illiquid due to the magnitude of the RAA-rata below the average industry standard of financial ratios. This means that where the company is able to pay off its short term obligations but is less able to manage the cash and current debts available within the company.

2. Based on the ratio of its solvability then it can be known that the company's financial position is seen from debt to total assets ratio and debt to equity ratio, then it can be said the average solvency level of PT. Indosat TBK for 4 years (year 2015 - year 2018 ) is in solvable position due to the average industry standard of financial ratios. This indicates that the state of the company's capital is adequate (good) to guarantee its hutang-hutangnya. If the debt level of each year is higher then it will further reduce the profits earned by the company.

3. Based on the ratio of profitability for 4 years (year 2015 - year 2018) can be seen the financial performance of PT. Inodosat TBK If from average net profit margin can be said to be efficient because it is above the average industry standard of financial ratios Whereas if viewed from the average return on assets and return on equity can be said to be inefficient because it is below average industry standard of financial ratios. This indicates that the company is in a poor position. This means that the company cannot generate profit annually and is not efficient in carrying out daily operations with its assets because the existing assets have not been fully utilized optimally. If the assets can be faster spin then the company will get the maximum profit. 
4. Based on the ratio of activities seen from the average total assets turnover of PT. Indosat TBK. For 4 years (year 2015 - year 2018) can still be said well because it shows an increase from year to year. But the average of PT. Indosat is said to be less less efficient because it is below the industry average of the financial ratios. This signifies the position of the company's performance in the performance position of the company is in poor condition (ineffective) in managing its resources so that the resulting profit is not maximal.

\section{Suggestion}

Based on the results of analysis and conclusions outlined above, the suggestions that can be given in this study are:

1. The company should increase the liquidity level more by utilizing its assets optimally so that in the next year there is an optimal improvement.

2. At the level of solvency, the company is in a good position but preferably for the next year should the company reduce the number of debts and better prioritize the use of assets that exist in the operation so that the company does not have difficulties in paying debts in the future.

3. The company should be able to increase sales productivity by emphasizing or managing the company's costs more efficiently to be expected annually that the company can generate a growing profit.

4. In its activity, the company is in a position less good. This situation can be repaired by increasing the level of its activity especially at the turnover of assets so that the use of assets annually is more effective and efficient.

\section{REFERENCES}

Anwar, K., Marliani, G., \& Indra, C. (2016). Financial Ratio Analysis for Increasing the Financial Performance of the Company at Bank Bukopin. International Journal of Sciences: Basic and Applied Research (IJSBAR), 29 (2), 231-236.

Ayu, ID, \& Sriratna, R. (2016). Evaluating FINANCIAL PERFORMANCE OF PT. PLAZA INDONESIA REALTY TBK. 16 (04), 35-46.

Agus Sartono. 2001. Financial Management Theory and Applications Yogyakarta. BPEFYOGYAKARTA.

Bambang Riyanto. 2008. Fundamentals Pembeajaran Company. Yogyakarta. Publisher GPFE.

Dadue, R., Saerang, IS, \& Ou, VN (2014). Financial Performance Analysis of Cement Industry Listed in Indonesia Stock Exchange. EMBA Journal, 2 (3), 1781-1791.

Fahmi, Irham. 2012. Analysis of Financial Performance. Bandung. Alfabeta.

Harahap, SS 2015. Critical Analysis of Financial Statements. Second Edition. Jakarta. PT. King Grafindo Persada.

Harmono. 2014. Financial Management: based on a balanced scorecard. Jakarta. Earth Literacy.

Kasmir. 2008. Analysis of Financial Statements. Jakarta. Publisher PT. Rajafindo Persada.

Kasmir. 2012. Analysis of Financial Statements. Jakarta. PT. RajaGrafindo Persada.

Kasmir. 2015 Financial Statement Analysis. First Edition. Eighth mold, Jakarta. PT. RajaGrafindo Persda.

Kuncoro, Mudrajat. 2009. Research Methods for Business and Economics. Jakarta. Erland. 